\title{
Coevolutionary Competence in the Realm of Corporate Longevity: How Long-lived Firms Strategically Renew Themselves
}

\author{
Zenlin Kwee, Frans A.J. Van Den Bosch and Henk W. Volberda
}

\begin{tabular}{|l|l|}
\hline \multicolumn{2}{|l|}{ ERIM REPORT SERIES RESEARCH IN MANAGEMENT } \\
\hline ERIM Report Series reference number & ERS-2007-076-STR \\
\hline Publication & November 2007 \\
\hline Number of pages & 39 \\
\hline Persistent paper URL & \\
\hline Email address corresponding author & zkwee@rsm.nl \\
\hline Address & Erasmus Research Institute of Management (ERIM) \\
& RSM Erasmus University / Erasmus School of Economics \\
& Erasmus Universiteit Rotterdam \\
& P.O.Box 1738 \\
& 3000 DR Rotterdam, The Netherlands \\
& Phone: $\quad+31104081182$ \\
& Fax: $\quad+31104089640$ \\
& Email: info@erim.eur.nl \\
& Internet: $\quad$ www.erim.eur.nl \\
\hline
\end{tabular}

Bibliographic data and classifications of all the ERIM reports are also available on the ERIM website: www.erim.eur.nl 


\section{ERASMUS RESEARCH INSTITUTE OF MANAGEMENT}

\section{REPORT SERIES}

\section{RESEARCH IN MANAGEMENT}

\begin{tabular}{|l|l|}
\hline ABSTRACT AND KEYWORDS \\
\hline Abstract & $\begin{array}{l}\text { Understanding the phenomena of corporate longevity and self-renewing organizations has } \\
\text { become an important topic in recent management literature. However, the majority of the } \\
\text { research contributions focus on internal determinants of longevity and self-renewal. Using a co- } \\
\text { evolutionary framework, the purpose of this paper is to address the dynamic interaction between } \\
\text { organizations and environments in the realm of sustained strategic renewal, i.e. corporate } \\
\text { longevity. To this end, we will focus on the competence of long-lived firms to coevolve due to the } \\
\text { joint effect of managerial intentionality and environmental selection pressures. Building on } \\
\text { coevolutionary framework, we develop a conceptual framework that highlights an organization's } \\
\text { coevolutionary competence. Two longitudinal case studies are presented illustrating the } \\
\text { arguments. }\end{array}$ \\
\hline Free Keywords & $\begin{array}{l}\text { Competence-based management, Coevolutionary competence, Corporate longevity, Strategic } \\
\text { renewal, Adaptive open systems }\end{array}$ \\
\hline Availability & $\begin{array}{l}\text { The ERIM Report Series is distributed through the following platforms: } \\
\text { Academic Repository at Erasmus University (DEAR), DEAR ERIM Series Portal } \\
\text { Social Science Research Network (SSRN), SSRN ERIM Series Webpage } \\
\text { Research Papers in Economics (REPEC), REPEC ERIM Series Webpage }\end{array}$ \\
\hline Classifications & $\begin{array}{l}\text { The electronic versions of the papers in the ERIM report Series contain bibliographic metadata } \\
\text { by the following classification systems: } \\
\text { Library of Congress Classification, (LCC) } \underline{\text { LCC Webpage }} \\
\text { Journal of Economic Literature, (JEL), JEL Webpage } \\
\text { ACM Computing Classification System CCS Webpage } \\
\text { Inspec Classification scheme (ICS), ICS Webpage }\end{array}$ \\
\hline
\end{tabular}




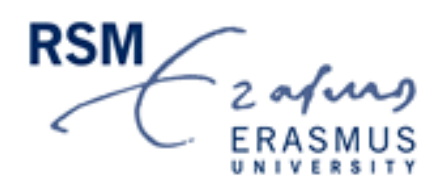

\title{
COEVOLUTIONARY COMPETENCE IN THE REALM OF CORPORATE LONGEVITY How Long-lived Firms Strategically Renew Themselves *)
}

\author{
Zenlin Kwee \\ Frans A.J. Van den Bosch \\ Henk W. Volberda \\ Erasmus University Rotterdam
}
Chapter accepted in R. Sanchez and A. Heene:
Research in Competence-Based Management (RCBM), 2007, Volume 4, Elsevier
Department of Strategy and Business Environment
Erasmus Strategic Renewal Center
RSM Erasmus University
Room T07-29, Burg. Oudlaan 50
P.O. Box 1738, 3000 DR Rotterdam
The Netherlands

Tel: +31 104081941 / 4082005

Fax: +31 104089013

E-mail: zkwee@rsm.nl

www.strategyaterasmus.nl

\footnotetext{
*) We acknowledge the insightful comments of the Competence 2005 Conference reviewer of the paper, the comments given by participants during the Conference, and the feedback from the postconference reviewer.
} 


\title{
COEVOLUTIONARY COMPETENCE IN THE REALM OF CORPORATE LONGEVITY: How Long-lived Firms Strategically Renew Themselves
}

\begin{abstract}
Understanding the phenomena of corporate longevity and self-renewing organizations has become an important topic in recent management literature. However, the majority of the research contributions focus on internal determinants of longevity and self-renewal. Using a coevolutionary framework, the purpose of this paper is to address the dynamic interaction between organizations and environments in the realm of sustained strategic renewal, i.e. corporate longevity. To this end, we will focus on the competence of long-lived firms to coevolve due to the joint effect of managerial intentionality and environmental selection pressures. Building on coevolutionary framework, we develop a conceptual framework that highlights an organization's coevolutionary competence. Two longitudinal case studies are presented illustrating the arguments.
\end{abstract}

Keywords: Competence-based management; Coevolutionary competence; Corporate longevity; Strategic renewal; Adaptive open systems. 


\section{Introduction}

Corporate longevity, i.e. sustained strategic renewal, merits thorough investigation. The large volume of existing research has resulted in several prominent findings on the common organizational characteristics of long-lived firms. These characteristics are, among others: a strong sense of identity, a decentralized organization or a tolerant management style (De Geus, 1999; Collins \& Porras, 1999; Hall, 1997), sensitivity towards the environment, (De Geus, 1999; Cohen \& Levinthal, 1990; Volberda, 1998), and conservative financing policy (Hall, 1997; De Geus, 1999). However, these common characteristics focus mainly on the processes inside an organization.

Such a focus is not incorrect, but rather it is incomplete because investigating corporate longevity requires a more encompassing perspective on organizations. The pertinent perspective, such as viewing organizations as symbiotic interacting systems (Hicks \& Gullet, 1975), takes into account both internal aspects of organizations and the forces in their environments that set limits on organizational discretion and the strategic possibility of influencing these forces to increase the chance of survival. Hence, a more encompassing approach requires a framework in which both environmental selection and firm-level adaptation is captured (Aldrich, 1979, 1999).

Furthermore, a comprehensive understanding is required of how firms change and deal with environmental developments, like technological innovation and (de-)regulation, over time and what kinds of competences are required for self-renewal. This paper intends to address these issues. The focus is on the competence of long-lived firms that enables them to dynamically remain aligned with the environment due to coevolutionary interaction between environmental selection and firm adaptation. Such competence is coined here as coevolutionary competence.

To this end, the purpose of this paper is to integrate the analytical perspective on competence-based management into a coevolutionary framework. In doing so, this paper aims to contribute to the literature in three ways. First, this paper will add to the richness of competence building and competence leveraging research through the integration with the coevolution theory. More specifically, it will contribute to the organizational competence framework by extending the dynamic, systemic, cognitive, and holistic aspect of management processes through the incorporation of three principles of self-renewal. Second, this paper contributes to the understanding of multidirectional causalities between collective managerial efforts and 
environmental changes. Third, the selection and adaptation perspectives on firms' longevity will be reconciled in this paper.

The paper is structured as follows. The first section discusses the idiosyncrasy of longlived firms to provide a brief review of previous research on corporate longevity. The second section elaborates on the emerging theory of coevolution and three principles of self-renewing organizations (Volberda \& Lewin, 2003) to give a theoretical framework for developing the notion of coevolutionary competence. The third section discusses the notion of coevolutionary competence to posit the ability regarding how firms may sustain the coordinated deployment of assets aimed at achieving their goals by coevolving with the environment. The fourth section presents two longitudinal case studies of long-lived firms, namely The Hudson's Bay Company (Canada) and Royal Ten Cate (The Netherlands). Both case studies aim at illustrating key aspects of the concept of coevolutionary competence. Finally, we summarize and pinpoint key findings of this study as well as highlighting issues for future research.

\section{The Idiosyncrasy of Long-lived Firms}

Why do firms vary so widely in the length and brevity of life? This question hardly crosses our minds. Perhaps this is because firms are all around us and thus we tend to take their existence for granted (Aldrich, 1979). We all have some interest in the survival of commercial firms since such organizations are necessary and important in our lives as purposive systems that enable us to accomplish collectively what cannot be accomplished by each of us as individuals acting on our own (Parsons, 1956; Aldrich, 1979). Hence, the existence of organizations plays an important role in our society and well-being.

However, the following facts regarding the average lifespan of firms highlight our research problem:

- The average life expectancy of Fortune 500 firms, from birth to death, is only 40 to 50 years. Their first 10 year is a period of high corporate 'infant mortality'. In addition, a full one-third of the 1970 Fortune 500 companies had been acquired or broken into segments, or had merged with other companies by 1983 (De Geus, 1997).

- In the past two decades, of the 20 largest US companies' bankruptcies, ten occurred in the last two years (Hamel \& Välikangas, 2003). 
- Among the companies on the original Forbes 100 list in 1917, 18 remained in the top 100 by 1987 and 61 had ceased to exist (Mackey \& Välikangas, 2004).

- The average life expectancy of all firms investigated, regardless of size, in Japan and much of Europe, is only 12.5 years (De Rooij, 1996).

- In the case of family companies, between first and second generations only about onethird of family businesses survive and, of those survivors, only 12 percent reach a third generation. An exclusive 3 to 4 percent of third generation survivors make it to a fourth (O’Hara, 2004).

Several researchers (e.g. De Geus, 1997; O’Hara, 2004; Kwee, 2004; Van Driel et al., 2004) identified a number of long-lived firms, ranging from family firms to large firms. Table 1 presents a few of these from many different countries around the world listed in an ascending order based on their year of origin. Two of the aforementioned long-lived firms, The Hudson's Bay Company (HBC) and Royal Ten Cate (RTC), are discussed in detail as the empirical case studies in the third section. Both companies are selected as they exemplify how a company is confronted with the regulatory, technological and other changes throughout their lifetime. They may, therefore, help to illustrate the construct of coevolutionary competence in the context of organizational longevity.

\section{Insert Table 1 about here}

How can these companies live for such a long time? Do they coincidentally pass the tests of survival through some Darwinian process of natural selection? Aldrich (1979) argued that the notion of "survival of the fittest" in natural selection is unable to explain what makes firms longlived. The natural selection model refers to a tendency for those species and organizations most fit vis-à-vis their environments to survive. Equating organizational "fitness" with "survival" would rob the model of any claim to scientific status and reduce it to a tautology in that it would provide only a post hoc explanation of why a firm failed but no a priori predictive base for assessing which ones will not in the future. However, in terms of likelihoods and probabilities, the presumption remains that a thriving organization is adaptable to its environment.

Evolution in Biology is often adopted as an approach to understanding corporate longevity just as the former is used to ascertain the longevity of human and other living organisms (e.g., Meyer \& Zucker, 1989; De Geus, 1999; Konz \& Katz, 2000). Analogously, 
many researchers (such as De Geus, 1997) regard firms as living entities. A firm has a life, with birth, all kinds of changes and death. The date of birth is the date of founding, and death or exit is considered to be the dissolution of the organization (Meyer \& Zucker, 1989: 70). Figure 1 illustrates our interpretation of a firm's life cycle. With respect to this cycle, long-lived firms are considered to be idiosyncratic: they seem to be able to relentlessly and reflectively renew themselves and thus make their life cycles last for centuries.

\section{Insert Figure 1 about here}

Within this framework, the foregoing research places a major emphasis on ascertaining which factors explain the longevity of firms (Collins \& Porras, 1999; De Geus, 1997; Hall, 1997; Huygens et al., 2001; Kwee, 2004). Their approach has been to a large extent inductive (except for Hall) and was performed by including multiple companies and subsequently investigating processes mainly inside the organizations. Their work pointed out common organizational characteristics that enable these long-lived firms to strategically renew themselves and adapt to the environment. However, these characteristics encompass, in particular, internal dimensions and are less clearly related to the environmental context.

Understanding the idiosyncrasy of long-lived firms requires a more comprehensive analysis than this analysis of their internal characteristics. Environmental factors have to be embedded in the analysis. In fact, explaining longevity demands a dynamic perspective to study how a particular firm develops over time through its capability to adapt to and influence the environment, including the role played by managerial intentionality (Lewin \& Volberda, 1999).

\section{Coevolution and Principles of Self-renewing Organizations}

How do long-lived firms sustain their existence over time? Under which conditions do firms adopt strategies for survival (and even, quite often, fail) as circumstances change? And how are disruptive or unwanted influences dealt with? These illustrative questions are the extended version of the early research like De Geus's (1999) that posed the question of 'what makes long lived firms?' They are also formulated since many scholars and business practitioners have observed that environmental change outstrips organizational competence change. Barnett and Hansen (1996) elaborated such conditions known in evolutionary theory as the 'Red Queen' effect, a principle which was introduced by Van Valen (1973) suggesting: "For an evolutionary system, continuing development is needed just in order to maintain its fitness relative to the 
systems it is co-evolving with.". Very often, organizational transformation or adaptation is derailed due to difficulty in making strategic transitions. Bate (1994), for instance, pointed out that although organizations are always changing, the natural pace of change may be too slow, particularly in a hypercompetitive environment or one facing technological shifts (D’Aveni, 1994).

Several theories have been introduced by researchers in the context of studying the longterm transformation of organization. We briefly elaborate on a few of them. In the first place, the population ecology theory suggests that management makes little if any difference and firms should focus on what they do best until they are selected out (Aldrich, 1979; Lewin \& Volberda, 1999) as the market selects out firms which have the wrong competencies (Barnett et al., 1994; Barney \& Zajac, 1994). The idea here is that for the most part, organizations act on a simple principle: “If a given routine works, let's do more of it; if it does not work, let’s do less" (March, 1999). Next, the resource-based view of the firm supports the idea that idiosyncratic resources are the basis of a sustained competitive advantage and management should maximize unique core competencies (Lewin \& Volberda, 1999). Alternatively, organizational learning theory states that variation in performance results from environmental changes and from the firm's ability to adapt through learning (Lewin \& Volberda, 1999; Kwee et al., 2006). The Royal Dutch Shell’s scenario planning, for instance, is viewed as a strategic learning media to help the company discern the relevant signals for (future) change and to understand how innovations were generated and how the transitional period was managed.

The increasing turbulence of the business environment has also changed the competitive game substantially and focused attention on knowledge as a dominant source of competitive advantage (Grant, 1996; Kogut \& Zander, 1992; Nonaka \& Takeuchi, 1995). Firms should access new outside knowledge, integrate it flexibly across different firm boundaries, and apply it to commercial ends (Cohen \& Levinthal, 1990). This dynamic capability, referred to as absorptive capacity, is seen as a promising explanation of innovation (Jansen et al., 2005; Stock et al., 2001; Tsai, 2001), the exploration / exploitation trade-off (Lewin, Long \& Caroll, 1999; March, 1991), business performance (Lane et al., 2001; Tsai, 2001), intra-organizational transfer of knowledge (Szulanski, 1996) and inter-organizational learning (Lane \& Lubatkin, 1998).

Firms with higher levels of absorptive capacity tend to outperform other firms in that they are more proactive and exploit current opportunities (Cohen \& Levinthal, 1990; Van den Bosch 
et al., 1999). However, inability to opportunely adapt to the changing environment is one of the big hurdles of firms. Ossified firms have difficulty in facing the new challenge with their ill-fated strategies that tend to routinely maintain what they have been doing well. Hence, to absorb new knowledge and to develop new skills are important requisites for firms facing changing environments.

Moreover, there is also a need to reconcile the paradox of conflicting forces for change and stability (Volberda, 1998). These conflicting pressures have also long been recognized (e.g., Burns \& Stalker, 1961) and many scholars have explicitly discussed the dilemma (Poole \& Van de Ven, 1989; Handy, 1989; Kanter, 1988; Hampden-Turner, 1990). On the one hand, organizations tend to preserve their core competencies. But they should realize that if they preserve the stability, core competencies can become core rigidities (Leonard-Barton, 1992; Burgelman, 1994; Barnett et al., 1994) or a 'competence trap' (Levitt \& March, 1988; Levinthal \& March, 1993). On the other hand, although adaptation is needed as the pressure to change comes not just from threats to survival but also the desire to grow and be more successful, too much change will lead to chaos, loss of cultural glue, fatigue and organizational break-down (Volberda, 1996b) or the 'renewal trap' (Levitt \& March, 1988; Levinthal \& March, 1993). Freeman et al. (1984) pointed to the fact that learning and adjusting structure enhance the chance of survival only if the speed of response is commensurate with temporal patterns of relevant environments. In Lewin's (1951) terminology, there is a cycle of unfreeze, move, refreeze, which is often repeated.

Furthermore, Lewin and Volberda (1999: 526) emphasized the importance of the coevolution perspective defining coevolution: 'as the joint outcome of managerial intentionality, environment, and institutional effects'. Coevolution assumes that change may occur in all interacting populations of organizations. In other words, change can be recursive and need not be an outcome of either managerial adaptation or environmental selection but rather the joint outcome of managerial intentionality and environmental effects. Hence, coevolution incorporates the premise that adaptation and selection are not orthogonal forces but are fundamentally interrelated. Correspondingly, Volberda and Lewin (2003) proposed three key principles of selfrenewal that suggest how organizations can manage sustained self-renewal in times of increasing disorder. These key principles are depicted in Table 2. 
The three key principles, which we consider as a prerequisite of corporate longevity, reiterate that adaptation and selection are not completely opposite forces but are fundamentally interrelated: organization and environment coevolve (Lewin \& Volberda, 1999; Flier et al., 2003). Besides, long-lived firms have adapted to the environment and have shaped the environment through their actions over a long period of time. The appropriateness of the adaptation, or a dynamic fit with the environment, is found in the right proportion of exploitation and exploration actions that change with the environment. Additionally, the coevolutionary perspective has the potential to bridge the selection-variation-adaptation chasm to further develop insights into the mutation process of firms. This perspective addresses the less frequently examined questions of how organizations systematically influence their environments and how organizational environments, in turn, influence those organizations. In short, coevolution demonstrates how the interplay between managerial intentionality and environmental role may reinforce the renewal process in organizations. This concept, therefore, contributes to an encompassing understanding of corporate longevity.

\section{Competence-based Management and Coevolutionary Competence}

Sanchez, Heene and Thomas (1996) introduced a competence-based management framework that aims to incorporate and integrate dynamic, systemic, cognitive, and holistic aspects of organizations. Extending the model of the firm as an open system (Sanchez et al., 1996) recently Sanchez and Heene (2002) and Sanchez (2004) develop a taxonomy of five competence modes, each of which is distinguished by specific forms of flexibility it brings to an organization to respond to the changing circumstances in the environment. Each mode is further distinguished by the kinds of strategic options it creates for an organization.

The left hand side of Table 3 provides a summary of the five competence modes in which competence is defined as 'the ability to sustain the coordinated deployment of assets in ways that help a firm achieve its goals' (Sanchez et al., 1996: 8). This definition was derived by taking into account the four aspects of organizational competence: dynamic, systemic, cognitive, and holistic. We briefly reiterate these four aspects of organizational competence as follows:

1. Dynamic: for a firm's competence to be sustainable, it must respond to the dynamic changes of the external environment and of its own internal processes. To explain the essential feature of such sustainability, Sanchez (2004: 521) introduced the notion of 
organizational entropy which suggests that managers provide continuous inputs of energy and attention to maintain or improve the order and structure in a firm's value-creation process.

2. Systemic: a firm's competence must be able to manage the coordination of the firmspecific assets (within the boundaries of the firm) and the firm's addressable assets (assets that are beyond the boundaries of the firm through the interactions with other firms).

3. Cognitive: a firm's competence in enabling managers to be able to ascertain and assure that the deployment of a firm's assets needed to carry out the strategies of the firm and to create value in targeted markets are managed effectively and efficiently.

4. Holistic: a firm's competence in recognizing a firm's goal achievement through the collective coordination of the interest of its multiple stakeholders.

Built upon the above competence construct and the framework of five competence modes, this paper highlights how managerial intentionality and the impact of environmental selection influence these five modes (the right hand side of Table 3). The arrow of managerial intentionality, for instance, suggests that the impact of managerial intentionality on building a firm's coevolutionary competence increases from competence mode 5 (operating flexibility) to competence mode 1 (cognitive flexibility regarding alternative strategic logics). Due to the nature of the first competence mode i.e. cognitive flexibility to define alternative strategic logic, managerial intentionality is most clearly associated with competence mode 1. Likewise, the arrow of the impact of environmental selection on the respective competence modes indicates the increasing impact of environmental forces in selecting organizational competence from competence mode 1 to competence mode 5 . Environmental selection pressures are most clearly revealed in, and will have the most direct impact on competence mode 5 . The interplay between both impacts (arrows) will enable the development of coevolutionary competence over time.

\section{Insert Table 3 about here}

Still in the context of the competence-based approach, Sanchez and Heene (2002) and Sanchez (2004) highlighted the importance of using an adaptive open system - a system that promotes strategic options of how competences are built or can be changed within an organization. It also results in a form of flexibility that allows an organization to respond to the changing opportunities and threats in its environment. As we shall see later in the discussion of 
the empirical case studies, long-lived firms seem to exhibit such characteristic of an adaptive open system through their dynamic adaptability.

Similarly, Thompson (1967) pointed out that a truly open- or natural-system model does not take the environment as given, and does not assume a completely known or controllable internal structure. Instead, organizations are loosely coupled systems, and thus it is possible for them to change at the level of specific activities or components. Sometimes organizations merely react to environmental selection, whereas in other instances members are active in managerial intentionality with the purpose of challenging the environment and perhaps even reshaping it. This is the key notion of coevolutionary which is the joint outcome of managerial intentionality, environment, and institutional effects (Lewin \& Volberda, 1999: 526).

Altogether, long-lived firms need not only possess competences as defined by Sanchez et al. (1996). To understand these firms, we suggest extending the definition of competence as a result of a distinctive kind of organizational flexibility to respond to changing and diverse environmental conditions, such as evolving market demands, technological change and competitive developments in an industry. The extended definition also has to address how collective action on the part of the firms molded the social and institutional environment in which firms operate (Murmann, 2003). The interaction between managerial intentionality and environmental selection as depicted in Table 3 inspires us to coin the construct of coevolutionary competence. Subsequently, by extending the definition of competence introduced by Sanchez et al. (1996: 8) we propose as a definition of coevolutionary competence: the ability to sustain the coordinated deployment of assets aimed at achieving a firm's goals by coevolving with the environment. In a sense a coevolutionary competence enables sustained renewal i.e. longevity. See table 4 depicting a coevolutionary competence framework.

\section{Insert Table 4 about here}

Coevolutionary competence includes the ability to respond to the dynamic nature of an organization's external environment and of its own internal processes. Firms must carefully manage their activities that collectively contribute to achieving organizational competence, interactions of different kinds and levels of these activities that are critical to the process of competence building (exploration) and leveraging (exploitation). To achieve this, they can use various organizational means, among others strategic architecture, concepts, tools, techniques and 
models a firm uses in combining resources and capabilities to build and leverage organizational competences (Hamel \& Heene, 1994). Accordingly, we suggest the following proposition:

\section{Proposition 1:}

Firms developing coevolutionary competence use the joint impact of both managerial intentionality and environmental selection on a firm's competence modes to implement the key principles of self renewal.

Developing a coevolutionary competence enables a firm to continuously balance the adequate strength of each competence mode. This ability is of paramount importance since as suggested by Sanchez (2004, p.528) any competence mode whose flexibility is not actually used is likely to diminish over time to a level that can cause a potential bottleneck. This bottleneck may limit the overall competence of the organization. To illustrate this bottleneck effect, we recaptured one figure from Sanchez (2004: 529 - Figure 2(b)) in Figure 2 below.

\section{Insert Figure 2 about here}

As depicted in Figure 2, firms having cognitive inflexibility at the top managerial level in competence modes I and II are confronted with bottlenecks that constrain the firm's overall potential for creating value. We assume, therefore, that in long-lived firms, due to the joint impact of both managerial intentionality and environmental selection on the competence modes, they are likely to be able to overcome such bottlenecks limiting their overall competence. This suggests the following proposition:

\section{Proposition 2:}

Firms developing coevolutionary competence are able to decrease bottlenecks in organizational flexibility in their competence modes.

\section{Illustrating Coevolutionary Competence: How Two Long-Lived Firms Strategically Renew Themselves}

In this section, two case studies - The Hudson's Bay Company (HBC) and Royal Ten Cate (RTC) - are presented to exemplify how long-lived firms develop and deploy a coevolutionary competence as part of their life-sustaining and self-renewal strategy. Among the long-lived firms mentioned in the introductory part of this paper, we eventually selected these two companies as our case study since they epitomize the long-lived firms that have confronted fundamental changes throughout their lifetime, such as regulatory changes or technological changes. In 
dealing with such changes, they are confronted with the two aspects of coevolution: managerial intentionality and environmental selection (please refer back to Table 3). Nevertheless, the experience of both companies is not impeccable. Obviously, there were frictions between environmental selection forces and the firms' adaptation, but management took the lessons and reshaped their firms to refit with the dynamic changes in their environments.

The case study method has been selected because in this paper, we do not test existing theories and want to highlight the process dimension and the multi-directional causalities. This research approach aims at preserving the chronological flow to see which historical events are likely to lead to which consequences. By doing so, we illustrate how coevolutionary competence may contribute to new integrations beyond the initial conceptions. The two case studies of HBC and RTC have resulted from our study of the longitudinal historical data of the two companies ranging from 1800 to 2000 (Kwee, 2004). Both companies were established before the year 1800. However, we considered the wide range of the period (1800-2000) as substantial enough for our early attempt to retrieve the long list of historical data that is either unavailable or incomplete during some of the periods. To start with, we briefly present the company profile of HBC and RTC as shown in Table 5.

Insert Table 5 about here

\section{Strategic Renewal of The Hudson's Bay Company (HBC)}

The Hudson's Bay Company (HBC) states explicitly in its Corporate Statement that it exists to provide Canadians with the widest selection of goods and services. HBC, which just celebrated its $336^{\text {th }}$ anniversary on May 2, 2006, has been a name Canadians can trust. It has a unique position in the country and a unique relationship with its customers. It is committed to building that relationship and earning that trust every day. Figure 3 below presents the company's timeline.

\section{Insert Figure 3 about here}

\section{Early Years}

For many centuries since its incorporation on May 2, 1670, the Hudson's Bay Company (HBC) enjoyed the stability of its monopoly. With the fur trading going well and its monopoly secured, HBC had settled into somewhat complacent daily routines - trapping, shipping and selling (its 
core competence at that time) - it no longer had ambitions in the field of exploration. This complacency caused the company to become less sensible to business signals from the environment in its early years (Competence trap). The company could not, for instance, take cognizance of the threat of other parties who were not satisfied with its privilege of the Royal Charter and could not adopt a good approach of negotiation and compromise. This situation continued until the company was forced to change by the Deed of Surrender in 1870 where it had to transfer much of its lands back to the Crown. HBC was forced to make the transition from being "absolute Lords" with exclusive trading rights to merchants in a newly opened pioneer land. The Deed of Surrender opened the company's eyes to the many new opportunities that it could exploit, such as the increasing demands from the Canadian settlers that opened up many channels to supply and deliver goods to them. Being able to learn from this situation, HBC took the appropriate action to fulfill this new demand.

\section{The 1800s}

The company's situation in the 1800s was changing since there was an emerging need to cooperate with external parties. One example is the union of HBC and the North West Company (previously HBC's most vigorous competitor), which later resulted in a merger in 1821. This union brought about a stronger and more complete Hudson's Bay Company with the additional valuable resources from the North West Company: its traders and voyageurs.

In the 1840s, a series of problems foreshadowed the beginning of the end for the HBC Charter. Despite being under the attack of pressures and protests, the company still showed its willingness to cooperate with the British Parliament for the review of its Charter that began in May of 1859. This situation persisted until the Deed of Surrender in 1870.

Immediately after the Deed of Surrender, the Hudson’s Bay Company established a Land Department to sell its land holdings to settlers, farmers, and developers. This is an indication of the company's willingness and ability to start building its network of cooperative relationships and further co-evolve with these stakeholders (cf. Sanchez, 2004) in the changing circumstances of Canadian inlands at that time. From the 1870s period onwards, HBC collaborated with Canadian Pacific Railway to build better delivery nodes to reach its customers in a step towards the realization of its ambition to be a closely-linked, stable commercial enterprise. This gradually caused HBC to begin to evolve into its present form as a consumer retailer. This started with the 
company's emergence into the early telecommunication business, as when over two million people settled to the west of the Great Lakes, Canada used the telegraph wires provided by HBC and the famous Canadian Pacific Railway. This strategic movement stretched HBC's way across the country through the former rich fur-trading lands of the company. Furthermore, the described changing signals also made it realize that it needed to expand its interests to meet the demands of a new breed of customer - the settler. It then began a wholesale department along with a large chain of HBC retail stores that became an important part of the daily lives of the settlers in the Canadian west.

\section{The 1900s onwards}

With the outbreak of World War I in 1914, the Hudson's Bay Company was called upon to engage in the most important duties in its history. This call made the company adjust its business models to become a vast system of steamship services for the transportation of food and munitions to France and later Russia.

When the War ended in 1918, HBC resumed its plans and actions exceptionally well in establishing a network of cooperative relationships. Some evidence: in 1925, HBC opened the great fur trade headquarters and auction house named Beaver House in London England; it opened wholesale offices in Paris and New York and accordingly built more supply chain partners; in 1927 the HBC collaborated with Continental Oil to investigate the very profitable business of oil exploration, via shared and received intelligence.

In the 1940s, HBC's adaptability decreased. This was mainly because of the inability of the company to sense the changing environment of the Depression in the 1930s and hence it decided not to be too aggressive as in the previous benign period. The outbreak of the Second World War, however, did not influence the company as much as in the first war as it had gained experience from the previous war. After the war ended and the situation was restored to normal, HBC continued to undergo major changes. The evidence showed, for instance, that it exploited its experience in interpreting the demand for fur outside Canada and consequently formulated its strategy to open the Company's auction houses in Montreal, New York and London. The auction houses enabled the large quantities of furs, which were collected by the Fur Department, to be sold on consignment. 
The jarring recession of 1981 derailed the company's ability to reinvent its business model as required by the signal of change it received. Nevertheless, the company was able to recover from the recession. Since then, it has managed to build a strong supply chain with its partners to support its largest department store retail chains and specialty stores. The other lesson the company kept in mind is not to be too aggressive in expansion as it could be both costly and risky. In the twenty first century, HBC is a thriving company, as it was back in the seventeenth century.

\section{HBC's Self-renewal Trajectory: Interactive Forces of Managerial Intentionality and Environmental Selection}

Reflecting on the chronological history of HBC, we summarize the self-renewal trajectory of $\mathrm{HBC}$ in terms of the company's coevolutionary competence as the dual role of managerial intentionality and environmental selection as presented in Figure 4. The diagram in the figure shows how HBC has developed its coevolutionary competence over time as a joint outcome of intentional adaptation directed by its management and environmental selection.

\section{Insert Figure 4 about here}

In the early 1800s, for instance, when the company was still operating under the Royal Charter, through the initiative of its management, HBC made a significant decision to merge with its strongest competitor - the North West Company - in 1821. This was then followed by the managerial movement to cooperate with the British Parliament to review its Royal Charter which led to the Deed of Surrender in 1870. Soon afterwards, HBC's top management collaborated with the Canadian Pacific Railway to explore the big potential demand of the new inhabitants in the Canadian inland and this signifies its first managerial movement after the company gave up its Royal Charter. In realizing this initiative, however, the company experienced a bottleneck effect at the operating flexibility level (please refer to Figure 5) in using its resources to cater for the new demand.

\section{Insert Figure 5 about here}

Nevertheless, the company's management eventually managed to solve this bottleneck issue through the gradual improvement it made due to its experiential learning throughout the partnership periods with the Canadian Pacific Railway. This brings us back to one of the essential feature of coevolutionary competence that we postulated in proposition 2 that a firm developing 
the coevolutionary competence realizes the importance of balancing each competence mode over time to decrease the bottleneck effects when dealing with changes in the environment.

In the 1900s, HBC managed to navigate through the ebb and flow of external selection forces related to the First and Second World Wars, the Economic Depression in 1930s, and the Jarring recession in 1981 through the strategic directions of its management such as the collaboration with Continental Oil in 1927, exploring fur markets outside Canada by opening auction houses in the 1950s that further led to the company's transformation into a retail chain nowadays. Such success, however, was not easily achieved. If we take a closer look at HBC's renewal trajectory by zooming in on the joint outcomes of managerial intentionality and environmental selection from 1930 to 2000 as depicted in Figure 6, we can notice that the crises happened when HBC did not perform well in balancing its managerial intentionality with the environmental forces.

\section{Insert Figure 6 about here}

For instance, during the Economic Depression in the 1930s and the Jarring recession in the 1980s when the environment became disruptive, HBC encountered turbulences that were difficult to counterbalance with its strategies. By almost the same token, during the 1970s HBC was in a vulnerable situation where it was too aggressive in its strategic acquisitions that exacerbated the crisis of 1981. Noticeable is that other than the crises and vulnerable periods, i.e. when HBC managed to balance its managerial intentionality with environmental forces, it experienced positive changes and growth. From the 1990s onwards, for instance, HBC continued to strategically establish strong supply chains with its partners and the efforts seem to have paid off as HBC nowadays has become one of the largest retail chains in Canada.

In conclusion, our analysis indicates that during significant changes bottlenecks (Sanchez, 2004) occurred in HBC's competence modes when the firm was not able to streamline the strategic initiatives at each level of the competence mode. Balancing the level of flow at each competence mode is of importance in helping the company to sustain its survival and its renewal trajectory. Moreover, when the environmental changes became disruptive there were periods when HBC's management restrained its intentionality or, when the level of its managerial intentionality was too aggressive in times of less turbulent environment, the company were in a critical or vulnerable situation. This situation suggests that it is essential that the company balance its managerial intentionality with environmental selection over time. 


\section{Strategic Renewal of Royal Ten Cate (RTC)}

In its Corporate Statement, Royal Ten Cate states that it seeks to achieve international leadership in niche markets on the basis of technological commitment and innovative capacity. The company focuses on materials with functional characteristics in the field of safety and protection (people and the environment), durability and specific technological and/or quality features. It values its employees by investing in their development potential for the transfer of expert knowledge (Kwee, 2004). The company timeline is presented in Figure 7.

\section{Insert Figure 7 about here}

\section{Early Years}

The historical archive of RTC in the early years is incomplete. Thus, the explanation of the company's experience during its early years is very limited. However, it is indicated that the company started with a small steam weaving mill with a trial-and-error method, do-first-and-seewhat-will-happen approach. This helped it learn to become stronger as it moved forward.

\section{The 1800s}

The period of 1800-1820 was still an explorative period for RTC in which it was only a commercial agent in the linen industry. At that time, the company was uncertain of the boundaries of its existence and even its raison d'être. It kept trying and using the traditional and conventional methods of the textile business without having a clear long-term vision. The operation was more or less static - it purchased yarns, distributed them among peasants (who processed them at home) and then sold the linen fabrics both at home and abroad. Such a pattern

of repetitive actions suggests that the company simply presumed that its business environment was more or less static. During this period, the company's cooperative relationships were limited only to the peasants, a few trading partners, and the local authority such as the Provincial Council of Overijssel. This network was a narrow one with no commitment to sharing knowledge. Thus, being in the routine daily operation, the company was not very keen on learning.

The period after 1830 was the beginning of change for RTC. In 1834, it was named $\mathrm{H}$. ten Cate Hzn. \& Co and in 1841 the firm switched to industrial textile production. During this early development, the company learned a lot (from the past) about weaving mills and further started up the Holland Steam Weaving Mill in 1860 (took effective actions based on past lessons). 
The period 1840-1860 was a period of increasing sensibility at RTC. Specifically in 1841, the firm was able to receive a signal regarding the potential need for industrial textiles with the advancement of weaving equipment at that time. Based on this signal, the firm switched to industrial textile production when it took over the almost bankrupt weaving mill of J.P. Lorey. Beginning around the 1850s, RTC became more cooperative with other stakeholders. The company joined forces with Twente entrepreneurs to eliminate the disadvantages of their region's geological barriers to trade and expansion. Together they contributed money for building canals (1855) and a rail network (1866) in their region. The company also joined the lobbying forces in the NV Twentsche Stoombleekerij (Tweente Steam Bleaching Works) in Goor (1857) to cut out the bleaching plants in Haarlem. Eventually, these partnerships did not continue and were not very relevant for its next phase of development.

The first mechanical weaving mill was set up in 1852 and RTC (at that time, its name was H. ten Cate Hzn. \& Co.) was conferred with the designation of 'Royal'. With this progress, it had a stronger resolve to forge ahead. This was then followed by the creation of Koninklijke Stoomweverij (KSW) or Royal Steam Weaving Mill in Nijverdal in 1872. Later on, the industrial textile initiative was expanded into the Holland Steam Weaving Mill (with about 160 power looms) the building of which had begun earlier. In 1891, the Tubantia Weaving Mill was opened and in 1898, the Java Weaving Mill was taken over.

\section{The 1900s onwards}

In 1912, when the Indië (East Indies) complex was started up, the company was adapted to the industrial textile environment in Almelo which was indicated by its opening of the Tubantia Weaving Mill and Java Weaving Mill. However, in the period after 1910 to the second half of the $20^{\text {th }}$ century (1950s), the decline of the Dutch textile industry went unnoticed by RTC. At this time, markets became more demanding and a number of formidable competitors appeared on the scene. Cut-throat competition grew both at home and abroad, mainly as a result of international supply capacity. There was also the need to increase work productivity by means of ongoing automation and to conquer new markets. Due to being less sensitive, RTC suffered as a result. In the 1950s, RTC became less adaptable because it could not learn from the changing environment of tougher competition. The company was not fast enough to adopt ongoing automation to increase its work productivity and conquer new markets. 
Fortunately, at the end of the 1960s and the beginning of the 1970s, the company was able to create a new perspective through the extensive restructuring of its industry. RTC made a timely switch-over to other technologies, raw materials and applications which enabled it to manage the entry to new markets. Moreover, prior to that, RTC demonstrated a fairly new ability to benefit from interdependencies in the 1950s when its partnerships with KSW became stronger which further led to the merger in 1957. At that time, the businesses of both KSW (Koninklijke Stoomweverij) and H. ten Cate Hzn. \& Co. resembled each other, in both production processes and products. Therefore, their paths kept crossing. The co-evolution at this stage was not yet fully apparent since it had just begun.

In 1977, the divisional structure was introduced and later even transformed to a decentralized group structure in 1990. Although the company continued to face a turbulent period in the industrial textile business environment, through ongoing internationalization and differentiation, it grew in the 1980s and 1990s into an industrial company in technical textiles and technical components. One of its technical components named Bryte materials was later used in NASA's satellite for the Beagle II and the Mars Exploration Rover missions.

\section{RTC's Self-renewal Trajectory: Interactive Forces of Managerial Intentionality and}

\section{Environmental Selection}

Likewise the previous summary of HBC's self-renewal trajectory, Figure 8 illustrates the selfrenewal trajectory of RTC as a result of both managerial intentionality and environmental selection which shows the development of its coevolutionary competence.

\section{Insert Figure 8 about here}

As we can see in the diagram, when RTC was still operating under the traditional environment of the Dutch steam weaving mills industry in the early 1800s, to a large extent its management took the initiative to experiment with various conventional methods of textile production. The workers became very skillful and could produce textiles in an efficient way. The management, however, faced the limitation and continued to perceive strategic opportunities to create new product offers as the company was operating in a relatively stable and even stagnant environment. As a result, the bottleneck occurred at the top management level in terms of the cognitive flexibility to define strategic logics. Figure 9 below illustrates this bottleneck effect.

\section{Insert Figure 9 about here}


When the company underwent changes in the development of Dutch industrial textiles in the 1800 s to 1900 s, RTC subsequently took strategic action to switch to industrial textile production and establish three weaving mills - the Holland Steam Weaving Mill, the Tubantia Weaving Mill, and the Java Weaving Mill. This is an indication of the timely adaptation of RTC to the changing circumstances in the Dutch textile business and the potential textile demand when the Indie complex was opened. Simultaneously, such strategic adaptation also enabled the company to tackle the previous bottleneck effect and thus managed to move the company to the next stage of development.

Starting from 1910, the Dutch textile industry experienced declining growth and turbulent competitive environment. By zooming in on the period 1910 to 1990 (as shown in Figure 10), we can see that RTC started experiencing difficulties at the end of the 1910s as the environment became harsh. The situation worsened when it could not increase the level of its managerial intentionality. Only after a while, starting at the end of the 1960s the company managed to counterbalance the environmental forces with its strategic actions. Among other reasons through its management initiative, RTC merged with KSW, adopted new technologies to extend its competence to the manufacturing of technical textiles and technical components. This reiterates the importance of a firm to dynamically balance its managerial intentionality with environmental forces to its sustained strategic renewal.

\section{Insert Figure 10 about here}

To sum up, the abovementioned analysis leads to the conclusion that like HBC, RTC also encountered a period when bottlenecks (Sanchez, 2004) occurred in its competence mode flows, i.e. during the stagnancy of the Dutch industrial textile growth. The difference here is that RTC experienced the bottleneck in the cognitive flexibility (i.e. competence mode 1) rather than operating flexibility (i.e. competence mode 5) as in HBC's case. The experience of RTC afterwards reiterates that streamlining the flow at each competence mode is crucial for the firm's strategic renewal. In comparison to HBC, whose environmental turbulence is more varied across periods, RTC was in a relatively constant turbulent environment during the 1900s. Due to the slow adjustment of its level of managerial intentionality with the level of environmental selection, RTC experienced critical situations during longer periods (Figure 10: 1920s-1960s) than HBC. However, when the company managed to match with the level of environmental selection, it emerged to move to the new renewal stage. 


\section{Discussion and Conclusion}

The idiosyncrasy of long-lived firms lies in their puzzling ability to renew themselves over time. Conjoining the three key principles of self-renewal from the coevolutionary framework (Lewin and Volberda, 2003) and the five competence modes in the competence-based management framework (Sanchez et al., 1996; Sanchez \& Heene, 2002; Sanchez, 2004), this paper contributes to a more encompassing perspective on corporate longevity that takes into account both internal aspects of long-lived organizations and how these organizations cope with the forces in their environments.

Focusing on the competence of long-lived firms, we coin the construct of coevolutionary competence in this paper. We define this construct as 'the ability to sustain the coordinated deployment of assets aimed at achieving a firm's goals by coevolving with the environment.' Based on a coevolutionary framework (Table 4), we developed two propositions in this paper. The first proposition deals with the importance of the interaction between managerial intentionality and environmental selection for firms to develop coevolutionary competence in the implementation of the key principles of self-renewal. The second proposition suggests that firms developing coevolutionary competence are able to decrease bottlenecks in the organizational flexibility of their competence modes.

Both propositions are illustrated in the analysis of two longitudinal case studies: The Hudson's Bay Company (HBC) and Royal Ten Cate (RTC) in the period 1800-2000. Figure 4 and Figure 8 in this paper indicate how both companies have developed their coevolutionary competence through the interactive forces of managerial intentionality and environmental selection. These figures provide evidence for the first proposition. In investigating bottlenecks in organizational competence of both firms, Figure 5 and Figure 9 provide evidence for the second proposition. These figures show for example that when HBC encountered a bottleneck regarding its operating flexibility in the 1870s or when RTC encountered a bottleneck regarding its cognitive flexibility during the 1800s-1900s, both companies managed to solve the bottleneck problems by re-balancing each competence mode over time.

Since this paper is the first attempt to use the construct of coevolutionary competence in the realm of corporate longevity, we acknowledge that this construct is still in its infancy and thus deserves more future work in both theoretical and empirical parts. In this respect, we believe 
that our work in this paper can provide a new lens and new directions for research in competencebased management and corporate longevity.

A first challenge is to consider the theoretical enhancement of the coevolutionary competence notion. In this paper, we have looked at the five competence modes introduced by Sanchez \& Heene (2002) and Sanchez (2004) from the coevolutionary perspective (Lewin \& Volberda, 2003). There are two possible streams, either to perform a more in-depth analysis or a broader analysis. In the first stream, the study might be carried out in relation to another context of competence-based themes yet still in the coevolutionary framework. In the second stream, the levels of analysis can take place beyond the firm-level analysis as demonstrated by what we have done in this paper. A second challenge rests in the empirical study. While this paper presents two brief longitudinal case studies, we have not fully addressed the influence of the institutional environment or other macro-level environmental forces. This requires research examining the macro environmental influences on the coevolutionary competence of long-lived firms (see for example Flier et al., 2003).

Recent research regarding competence-based management investigates the level within the organization at which competences exist, the time horizon by which a competence is likely to apply, the knowledge base on which a competence depends, and the simplicity vs. the complexity of the processes behind the underlying competence (Sanchez, 2004). For example, some firms have competences that seem to arise from managing a complex web of interrelationships and coordinating a large number of interdependent processes, while other firms appear to have created competences by simplifying their processes and focusing on a small number of key valueadding activities (Baden-Fuller \& Volberda, 1997). For other firms, competences often appear to be contingent - i.e., to be capable of creating value in certain kinds of competitive contexts, but not necessarily in others (Winterscheid \& McNabb, 1996; Volberda, 1996a). The implication for the coevolutionary competence construct must be investigated in future research.

In conclusion, coevolutionary competence might be a useful construct for investigating strategic renewal of firms over time. The empirical research of the two long-lived firms posits that firms that continually renew themselves have a better chance to last for a long time. What is more, coevolutionary competence empowers firms to undergo significant internal long-term transformations. As a result, long-lasting firms stay vital by resisting decay. Coevolutionary competence raises the awareness of management to focus on the three principles of self-renewal 
(Table 2). This requires managing the tension between innovation (exploration) and adaptation (exploitation) through a dynamic adaptation to the changing environments, i.e. maintaining a balance between both. To achieve this, firms also need to focus on managing requisite variety by regulating internal rates of change to equal or exceed relevant external rates of change. Furthermore, firms should constantly strive to optimize self-organizing. Obviously, these challenges are not easy. Lacking managerial intentionality to cope with these challenges will result in not being able to coevolve with the environment. 


\section{References}

Adrich, H.E. (1979). Organizations and Environments. Englewood Cliffs, NJ: Prentice Hall.

Aldrich, H.E. (1999). Organizations Evolving. London: Sage.

Anderson, P. (1999). 'The Role of the Manager in a Self-organizing Enterprise'. In J. H. Clippinger (Ed.), The Biology of Business: Decoding the Natural Laws of Enterprise, San Francisco: Jossey-Bass.

Baden-Fuller, C. and Volberda, H.W. (1997). 'Strategic Renewal in Large Complex Organizations: A Competence-based View', in A. Heene and R. Sanchez (eds.), Competence-Based Strategic Management, Chichester: Wiley: 89-110.

Barnett, W. P., Greve, H.R. and Park, D.Y. (1994). 'An Evolutionary Model of Organizational Performance’. Strategic Management Journal, 15: 11-28.

Barnett, W.P. and Hansen, M.T. (1996). ‘The Red Queen in Organizational Evolution’. Strategic Management Journal, 17: 139-157.

Barney, J. (1991). 'Firm Resources and Sustained Competitive Advantage'. Journal of Management 17(1): 99-120.

Barney, J.B. and Zajac, E.J. (1994). 'Competitive Organizational Behavior: Toward an Organizationally-Based Theory of Competitive Advantage'. Strategic Management Journal, 15: 5-9.

Bate, P. (1994). Strategies for Cultural Change. Oxford: Butterworth Heinemann.

Burgelman, R.A. (1994). 'Fading Memories: A Process Theory of Strategic Business Exit in Dynamic Environments'. Administrative Science Quarterly, 39: 24-56.

Burns, T. and Stalker, G. (1961). The Management of Innovation. Tavistock, London.

Cohen, W. M. and Levinthal, D.A. (1990). 'Absorptive Capacity: A New Perspective on Learning and Innovation', Administrative Science Quarterly, 35(1): 128-152.

Collins, J.C. and Porras, J.I. (1999). Built to Last: Successful Habits of Visionary Companies. New York: Random House Business Books.

D’Aveni, R. (1994). Hypercompetition. New York: Free Press.

De Geus, A. (1999). The Living Company: Growth, Learning and Longevity in Business. London: Nicholas Brealey Publishing. 
De Rooij, E. (1996). A Brief Desk Research: Study into the Average Life Expectancy of Companies in a Number of Countries. Stratix Consulting Group, Amsterdam, August 1996.

Freeman, J., Carroll, G.R., and Hannan, M.T. (1983). 'The Liability of Newness: Age Dependence in sOrganizational Death Rates'. American Sociological Review, 48 (October): 692-710.

Flier, B., Van Den Bosch, F.A.J. and Volberda, H.W. (2003). 'Coevolution in the Strategic Renewal Behaviour of British, Dutch and French Financial Incumbents: Interaction of Environmental Selection, Institutional Effects, and Managerial Intentionality', Journal of Management Studies, 40(8): 2163-2187.

Grant, R.M. (1996). 'Prospering in Dynamically-Competitive Environments: Organizational Capability as Knowledge Integration’, Organization Science, 7(4): 375-387.

Hall, R. (1997). ‘Long Term Survivors’. Journal of General Management, 4(Summer): 1-15.

Hamel, G. and Heene, A. (1994). Competence-Based Competition. New York: Wiley.

Hamel, G. and Välikangas, L. (2003). The Quest for Resilience, HBR, Harvard Business School Publishing Corporation, September: 1-13.

Hampden-Turner, C. (1990). Charting the Corporate Mind. New York: Free Press.

Handy, C. (1995). The Age of Unreason, London: Arrow Business Books.

Hicks, H. Gullet, C.R. (1975). Organizations: Theory and Behaviour. New York: McGraw Hill.

Huygens, M., Baden-Fuller, C., Van den Bosch, F.A.J., Volberda, H.W. (2001). 'Coevolution of Firm Capabilities and Industry Competition: Investigating the Music Industry, 18771997’. Organization Studies, 22(6): 971-1011.

Jansen, J.J.P., Van den Bosch, F.A.J., \& Volberda, H.W. (2005). 'Managing Potential and Realized Absorptive Capacity: How do Organizational Antecedents Matter?' Academy of Management Journal, 48(6): 999-1015.

Kanter, R. M. (1988). `When a Thousand Flowers Bloom: Structural, Collective, and Social Conditions for Innovation in Organization', in B. M. Staw and L. L. Cummings (eds.), Research in Organizational Behavior, Vol.10, Greenwich, Connecticut: JAI Press: 169211. 
Kogut, B. and Zander, U. (1992). 'Knowledge of the Firm, Combinative Capabilities, and the Replication of Technology', Organization Science, 3(3): 383-397.

Konz, G.N.P. and Katz, J.A. (2000). 'Metapopulation Analysis: A Technique for Studying Hyperlongevity’. Journal of Organizational Change, 13(1): 49-60.

Kwee, Z. (2004). Corporate Longevity: What Makes Eight of the 200+-year-old Companies So Resilient? MSc. Thesis, Delft: Delft University of Technology (TU Delft) - Faculty of Technology, Policy and Management.

Kwee, Z., Van den Bosch, F.A.J. and Volberda, H.W. (2006). 'Conceptualizing Learning Principles of Long-Lived Firms'. Paper accepted and to be presented at the 2006 Academy of Management Annual Meeting, Atlanta, Georgia.

Lane, P. J. and Lubatkin, M. (1998). 'Relative Absorptive Capacity and Interorganizational Learning, Strategic Management Journal, 19: 461-477.

Lane, P.J., Salk, J.E. and Lyles, M.A. (2001). 'Absorptive Capacity, Learning, and Performance in International Joint Ventures’. Strategic Management Journal, 22: 1139-1161.

Leonard-Barton, D. (1992). 'Core Capabilities and Core Rigidities: A Paradox in Managing New Product Development’. Strategic Management Journal, 13(Special Issue): 111-125.

Levinthal, D. A. and March, J.G. (1993), 'The Myopia of Learning', Strategic Management Journal, 14(Special Issue): 95-112.

Levitt, B. and March, J. G. (1988). 'Organizational learning'. In Scott, W. R. (Ed.). Annual review of sociology. 14, Annual Reviews, Palo Alto, CA: 319-340.

Lewin, K. (1951). Field Theory in Social Science. New York: Harper and Row.

Lewin, A. Y., Long, C. P. and Carroll, T. N. (1999). 'The Coevolution of New Organizational Fsorms’. Organization Science 10(5): 535-50.

Lewin, A.Y. and Volberda, H. W. (1999). 'Prolegomena on Coevolution: A Framework for Research on Strategy and New Organizational Forms’. Organization Science, 10(5): 519534.

Mackey, J. and Välikangas, L. (2004). 'The Myth of Unbounded Growth'. MIT Sloan Management Review, Winter 2004: 89. 
March, J.G. (1991). 'Exploration and Exploitation in Organizational Learning'. Organization Science, 2(1): 71-87.

McKelvey, B. (2003). 'Micro Strategy and Macro Leadership: New Science Meets Distributed Intelligence'. In A. Y. Lewin and H.W. Volberda (Eds.), The Coevolution Advantage: Mobilizing the Self-Renewing Organization, Armonk, NY: M.E. Sharpe.

Meyer, M.W. and Zucker, L.G. (1989). Permanently Failing Organizations. Sage Publications.

Murmann, J.P. (2003). Knowledge and Competitive Advantage: The Coevolution of Firms, Technology, and National Institutions. UK: Cambridge University Press.

Nelson, R. and Winter, S. (1982). An Evolutionary Theory of Economic Change. Cambridge, MA: Belknap Press.

Nonaka, I. (1988). 'Creating Organizational Order out of Chaos: Self-Renewal in Japanese Firms’, California Management Review, 30(3): 57-73.

Nonaka, I. and H. Takeuchi (1995). The Knowledge-creating Company. New York: Oxford University Press.

O’Hara, W.T. (2004). Centuries of Success: Lessons from the World's Most Enduring Family Businesses. Canada: Adams Media.

Parsons, Talcott (1956). Suggestions for a Sociological Approach to the Theory of Organizations. Administrative Science Quarterly, 1 (June and September): 63-85, 225-39, respectively.

Poole, M. S. and Van de Ven, A.H. (1989). 'Using Paradox to Build Management and Organization Theories', Academy of Management Review, 14(4): 562-578.

Sanchez, R., Heene, A., and Thomas, H. (1996). Towards the Theory and Practice of Competence-Based Competition. In: Sanchez, R., Heene, A. and Thomas, H., Editors, 1996. Dynamics of Competence-Based Competition: Theory and Practice in the New Strategic Management, London: Elsevier: 1-35.

Sanchez, R., and Heene, A. (2002). 'Managing Strategic Change: A Systems View of Strategic Organizational Change and Strategic Flexibility'. Systems Perspectives on Resources, Capabilities, and Management Processes, London: Elsevier, Chapter 5: 71-91.

Sanchez, R. (2004). 'Understanding Competence-based Management: Identifying and managing five modes of competence'. Journal of Business Research, 57: 518-532. 
Stock, G.N., Greis, N.P. and Fischer, W.A. (2001). 'Aborptive Capacity and New Product Development’. The Journal of High Technology Management Research, 12: 77-91.

Szulanski, G. (1996). 'Exploring Internal Stickiness: Impediments to the Transfer of Best Practice within the Firm', Strategic Management Journal, 17 (Winter Special Issue): 2743.

Thompson, J. D. (1967). Organizations in Action. New York: McGraw-Hill.

Tsai, W. (2001). 'Knowledge Transfer in Intraorganizational Networks: Effects of Network Position and Absorptive Capacity on Business Unit Innovation and Performance'. The Academy of Management Journal, 44(5): 996-1004.

Van den Bosch, F.A.J., Volberda, H.W. and De Boer, M. (1999), 'Coevolution of Firm Absorptive Capacity and Knowledge Environment: Organizational Forms and Combinative Capabilities’, Organization Science, 10(5): 551-568.

Van Driel, H., Volberda, H.W., Eikelboom, S. (2004). 'Longevity in Services: The Case of the Dutch Warehousing Companies 1600-2000'. Paper for the 8th EBHA Conference, Barcelona, September 16-18, 2004.

Van Valen, L. (1973). ‘A New Evolutionary Law’. Evolutionary Theory 1: 1-30.

Volberda, H.W. (1996a). 'Flexible Configuration Strategies within Philips Semiconductors: A Strategic Process of Entrepreneurial Revitalization'. In: Sanchez, R., Heene, A. and Thomas, H., Editors, 1996. Dynamics of competence-based competition: theory and practice in the new strategic management, Elsevier, London: 229-278.

Volberda, H. W. (1996b). 'Towards the Flexible Firm: How to Remain Vital in Hypercometitive Environments’. Organizational Science, 7(4): 359-374.

Volberda, H.W. and Lewin, A.Y. (2003). Co-evolutionary Dynamics Within and Between Firms: From Evolution to Co-evolution. Journal of Management Studies, 40 (8): 2111-2136.

Winterscheid, B.C. and McNabb, S. (1996). 'From National to Global Product Development Competence in the Telecommunications Industry: Structure and Process in Leveraging Core Capabilities’. In: Sanchez, R., Heene, A. and Thomas, H., Editors, 1996. Dynamics of Competence-Based Competition: Theory and Practice in the New Strategic Management, Elsevier, London: 279-298. 


\section{TABLES}

Table 1. List of Several Long-lived Firms

\begin{tabular}{|c|c|c|c|}
\hline Company Name & $\begin{array}{l}\text { Year of } \\
\text { Origin }\end{array}$ & Country & Current Line of Business \\
\hline Kongo Gumi & 578 & Japan & Temple restoration and construction \\
\hline $\begin{array}{l}\text { Stora (present: } \\
\text { Stora Enso) }\end{array}$ & 1288 & Sweden & Integrated paper, packaging, and forest products \\
\hline $\begin{array}{l}\text { Cambridge } \\
\text { University Press }\end{array}$ & 1534 & U.K. & Printing and publishing \\
\hline $\begin{array}{l}\text { Royal Pakhoed } \\
\text { (present: Vopak) }\end{array}$ & 1600 & $\begin{array}{l}\text { The } \\
\text { Netherlands }\end{array}$ & $\begin{array}{c}\text { Transport, logistics (warehousing), and } \\
\text { distribution }\end{array}$ \\
\hline Van Eeghen & 1662 & $\begin{array}{l}\text { The } \\
\text { Netherlands }\end{array}$ & Food products and food ingredients \\
\hline Saint-Gobain & 1665 & France & $\begin{array}{l}\text { Producer, processor, and distributor of materials } \\
\text { (glass, ceramics, plastics, and cast iron) }\end{array}$ \\
\hline $\begin{array}{l}\text { The Hudson’s Bay } \\
\text { Company }\end{array}$ & 1670 & Canada & Department store retailer \\
\hline Royal Ten Cate & 1704 & $\begin{array}{l}\text { The } \\
\text { Netherlands }\end{array}$ & Technical textiles and technical components \\
\hline $\begin{array}{l}\text { The Royal Bank of } \\
\text { Scotland }\end{array}$ & 1727 & $\begin{array}{l}\text { U.K., } \\
\text { Scotland }\end{array}$ & Bank and Financial Services \\
\hline DuPont & 1802 & USA & $\begin{array}{c}\text { Chemicals, materials, energy, and science-based } \\
\text { solution provider }\end{array}$ \\
\hline
\end{tabular}


Table 2. A Prerequisite of Corporate Longevity: Three Principles of Self-renewal

\section{Three principles of self-renewal Explanation and references}

Self-renewing organizations focus on managing requisite

- $\quad$ The principle of managing variety by regulating internal rates of change to equal or internal rates of change exceed relevant external rates of change (e.g., competitors, technology, consumers, etc.) (McKelvey, 2003).

- $\quad$ The principle of optimizing Self-renewing organizations optimize self-organizing self-organization (Anderson, 1999; Nonaka, 1988)

- The principle of Self-renewing organizations synchronize concurrent synchronizing concurrent exploitation and exploration (Lewin and Volberda, 1999; exploration and exploitation

Lewin et al., 1999; March, 1991).

Source: Volberda and Lewin, 2003. 
Table 3. Coevolutionary Competence and a Firm's Competence Modes

\begin{tabular}{|c|c|c|}
\hline \multicolumn{2}{|c|}{$\begin{array}{l}\text { Source: Competence Modes: Sanchez and } \\
\text { Heene (2002) and Sanchez (2004) }\end{array}$} & This paper \\
\hline $\begin{array}{l}\text { Competence } \\
\text { Mode }\end{array}$ & Source of Competence Mode & $\begin{array}{c}\text { Relative Importance of Managerial } \\
\text { Intentionality and Environmental } \\
\text { Selection in Developing a } \\
\text { Coevolutionary Competence }\end{array}$ \\
\hline 1 & $\begin{array}{l}\text { Cognitive flexibility regarding } \\
\text { alternative strategic bogics }\end{array}$ & H \\
\hline 2 & $\begin{array}{l}\text { Cognitive flexibility regarding } \\
\text { alternative management processes }\end{array}$ & Managerial \\
\hline 3 & $\begin{array}{l}\text { Coordination flexibility regarding } \\
\text { resource chains }\end{array}$ & $\begin{array}{c}\text { intentionality } \\
\text { i }\end{array}$ \\
\hline 4 & $\begin{array}{l}\text { Resource flexibility regarding } \\
\text { range of uses in operations }\end{array}$ & selection \\
\hline 5 & $\begin{array}{l}\text { Operating flexibility regarding the } \\
\text { skills and capabilities of resources }\end{array}$ & $\mathrm{L} \perp$ \\
\hline
\end{tabular}

Note:

- $\quad \mathbf{H}$ (high): increasing influence of either the managerial intentionality or the impact of environmental selection on respective competence modes.

- $\quad \mathbf{L}$ (low): decreasing influence of either the managerial intentionality or the impact of environmental selection on respective competence modes. 
Table 4. The Coevolutionary Competence Framework

\section{Organizational Competence (Sanchez et al., 1996; Sanchez and Heene, 2002; Sanchez, 2004)}

-Definition: "the ability to sustain the coordinated deployment of assets in ways that help a firm achieve its goals." (Sanchez et al., 1996 p.8)

\section{Four aspects of the definition:}

(Sanchez 2004, p. 521)

1. Dynamic:

* Matching speed of change of external and internal processes

* Sustainability Organizational entropy

2. Svstemic: manage interactions with other organizations in terms of coordination of assets

3. Cognitive: managers are responsible for both efficient and effective use of an organization's assets

4. Holistic: goal achievement through the existence of multiple stakeholders

\section{Coevolutionary Competence} (This Paper)

-Definition: "the ability to sustain the coordinated deployment of assets aimed at achieving a firm's goals by coevoiving with the environment."

\section{Four aspects of the definition}

1. Dynamic:

${ }^{*}$ Relates to the first principle of seifrene wal (Volberda and Lewin, 2003)

* Sustainability is related to self-organizing - the second principle of self-renewal (Volberda and Lewin, 2003)

2. Svstemic: manage the nature of firm-environment interactions - relates to the third principle of self renewal: synchronize concurrent exploitation and exploration (Volberda and Lewin, 2003)

3. Cognitive: related to the role of managerial intentionality in coevolutionary processes

4. Holistic: goal achievement through the networking with multiple stakeholders

This paper adds to the definition as proposed by Sanchez et al. (1996), Sanchez and Heene (2002), and Sanchez (2004):

- More prominently highlighting the dynamics of the first principle and the second principle of self-organizing - Incorporating the third principle of self-renewal

-Explicitly recognizing managerial intentionality, e.g. deliberately influencing the environment 
Table 5. Brief Company Profile

\begin{tabular}{|c|c|c|}
\hline Company & $\begin{array}{l}\text { Year of } \\
\text { Origin }\end{array}$ & Brief Profile \\
\hline $\begin{array}{l}\text { The Hudson’s Bay } \\
\text { Company (HBC) - } \\
\text { www.hbc.com }\end{array}$ & 1670 & $\begin{array}{l}\text { Founded in } 1670 \text { as a fur trading company, HBC is Canada’s } \\
\text { oldest corporation. Today, it is also Canada's largest } \\
\text { department store retailer. The Company provides Canadians } \\
\text { with the widest selection of goods and services available } \\
\text { through numerous retail channels including more than } 500 \\
\text { stores led by the Bay and Zellers chains. Hudson's Bay } \\
\text { Company is Canada's fifth largest employer with 70,000 } \\
\text { associates and has operations in every province in Canada. Its } \\
2003 \text { annual revenue was USD 4,830.5 million. }\end{array}$ \\
\hline $\begin{array}{l}\text { Royal Ten Cate } \\
\text { (RTC) - } \\
\text { www.tencate.com }\end{array}$ & 1704 & $\begin{array}{l}\text { The earliest written announcements concerning the activities of } \\
\text { Royal Ten Cate date from } 1704 \text { as one of the Dutch textile } \\
\text { producers. Today, Ten Cate is active in two sectors: Technical } \\
\text { Textiles and Technical Components. Operating in } 15 \text { countries } \\
\text { and four continents, the company creates textiles and materials } \\
\text { that people use for a wide range of purposes, from strong and } \\
\text { light aerospace materials to antiballistic fabrics and flame- } \\
\text { retardant fabric coatings. The company also manufactures } \\
\text { textiles and other materials used in civil engineering, } \\
\text { agriculture, fashion, and artificial turf. As of the fiscal year } \\
\text { which ended in December 2002, the company had around } \\
\text { 3,278 employees and USD 631.1 million of annual sales. }\end{array}$ \\
\hline
\end{tabular}




\section{FIGURES}

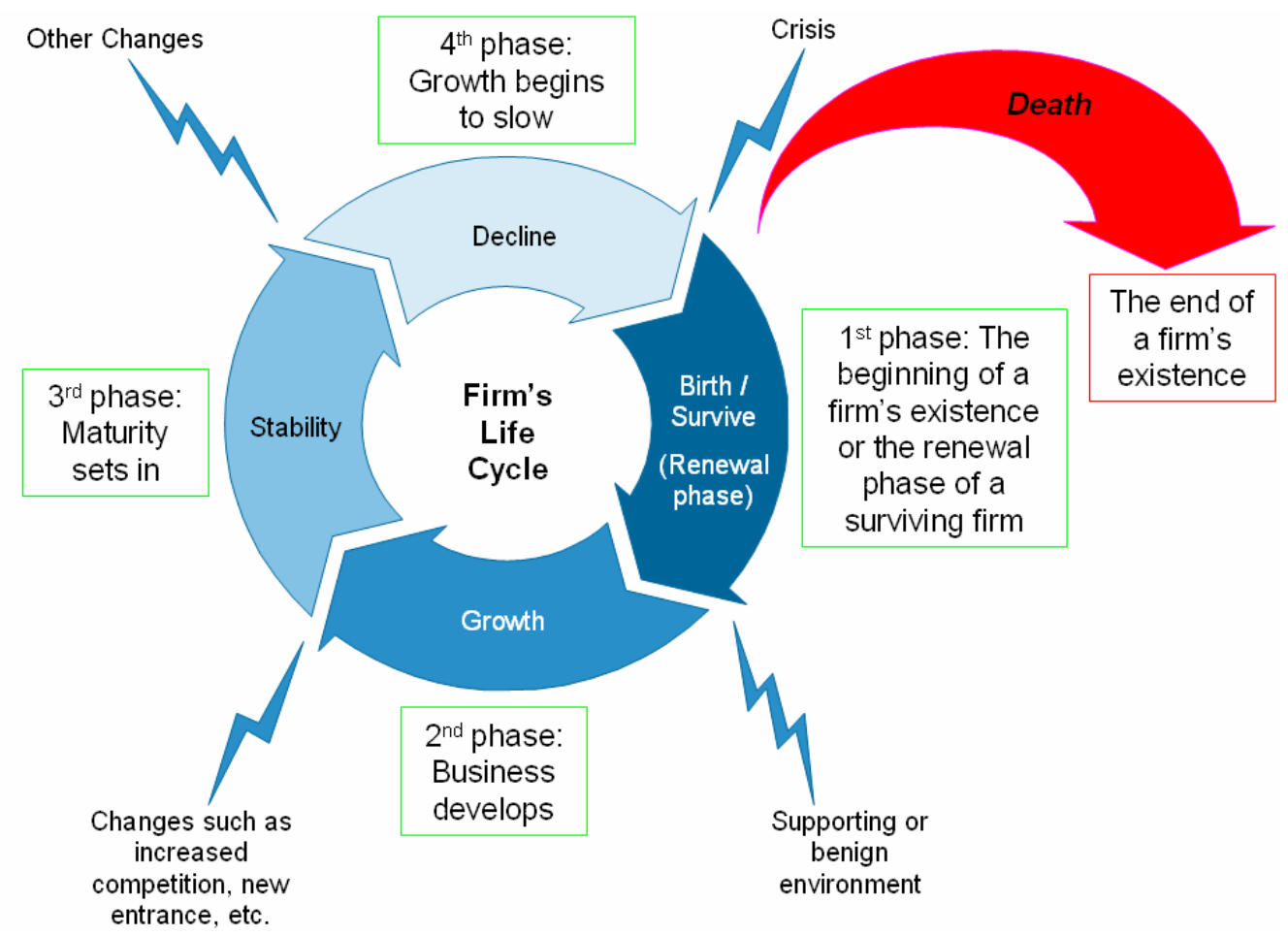

Figure 1. Firm's life cycle

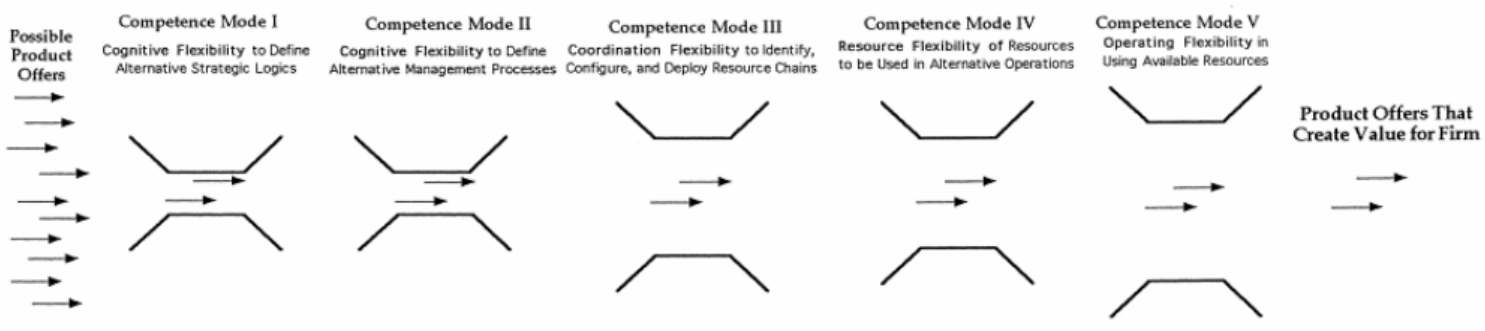

Figure 2. Competence profile with "bottleneck" in competences modes I and II - recaptured from Sanchez (2004, Figure 2(b): p.529) 


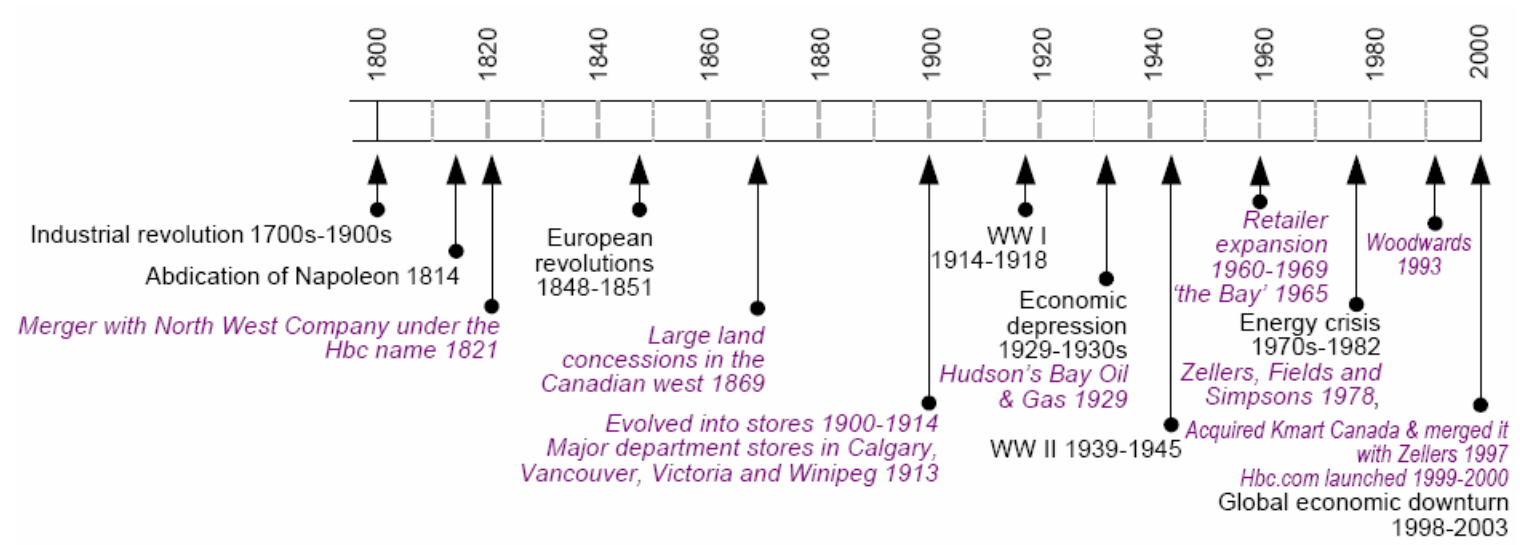

Figure 3. HBC's Company Timeline (Italics fonts: Firm-specific historical events; Regular fonts: Global historical events)

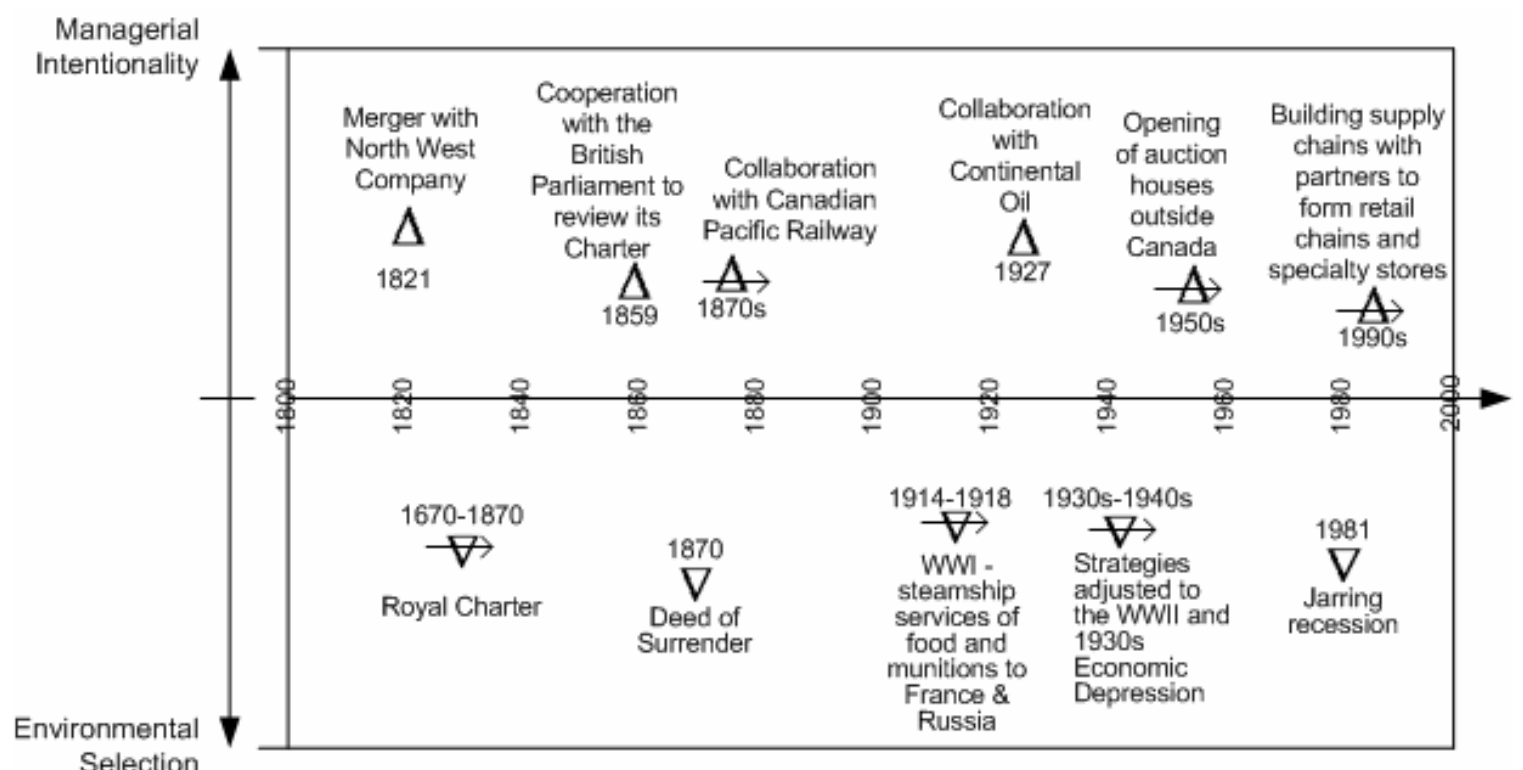

Figure 4. HBC’s Self-renewal Trajectory Snapshot

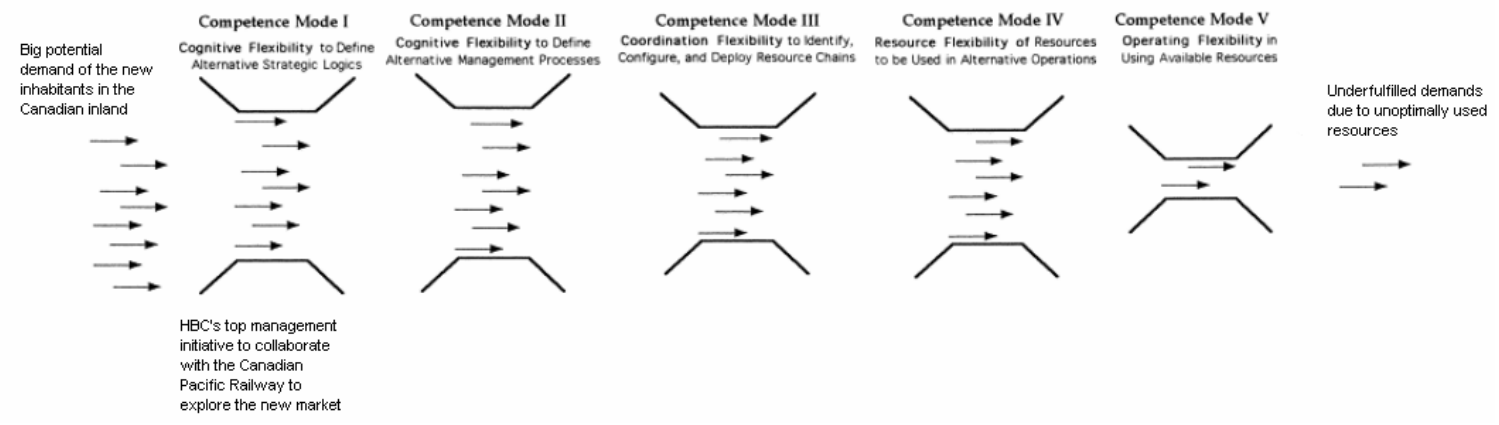

Figure 5. Bottleneck in the operating flexibility level during the HBC's management initiative in exploring new market through the collaboration with the Canadian Pacific Railway in the 1870s 


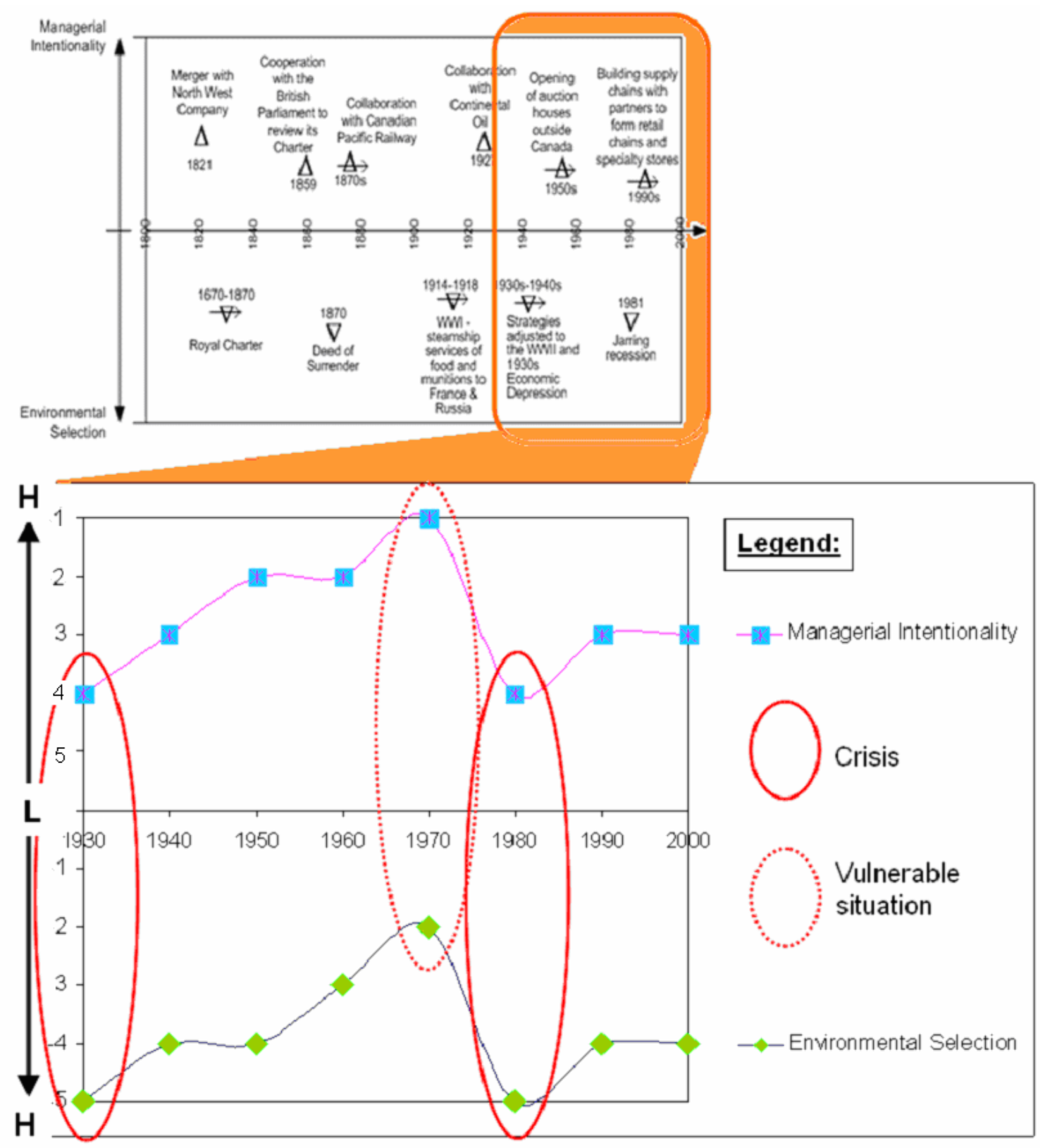

Figure 6. Zooming in on HBC's Renewal Trajectory (1930-2000) 


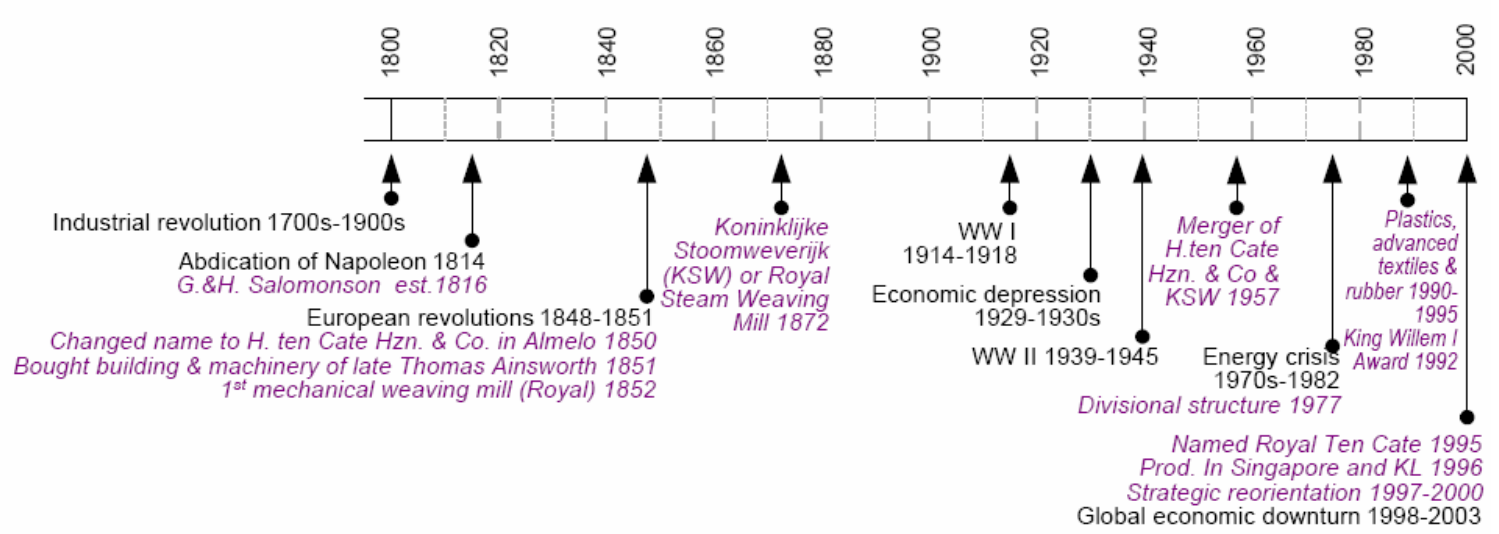

Figure 7. RTC's Company Timeline (Italics fonts: Firm-specific historical events; Regular fonts: Global historical events)

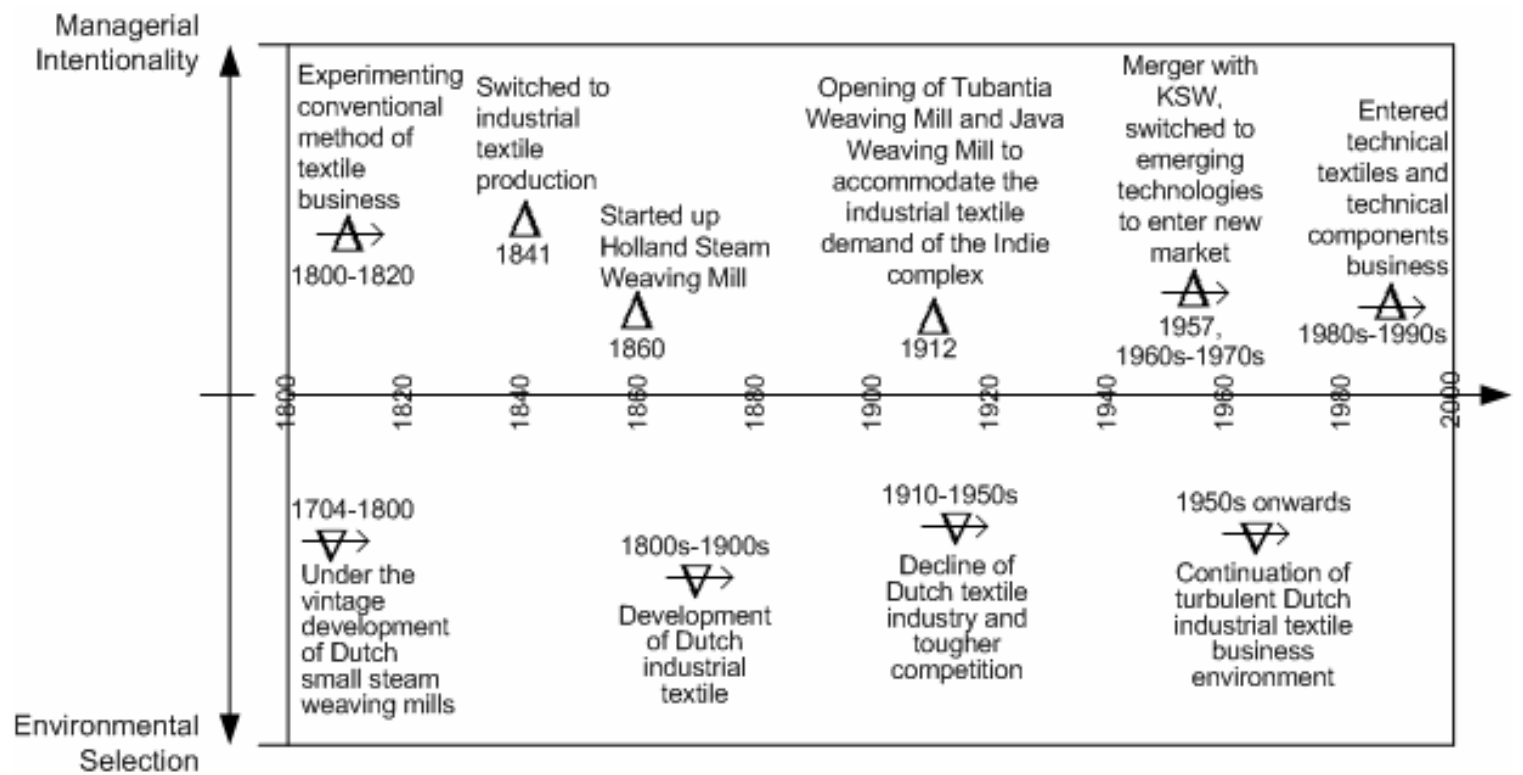

Figure 8. RTC’s Self-renewal Trajectory Snapshot 


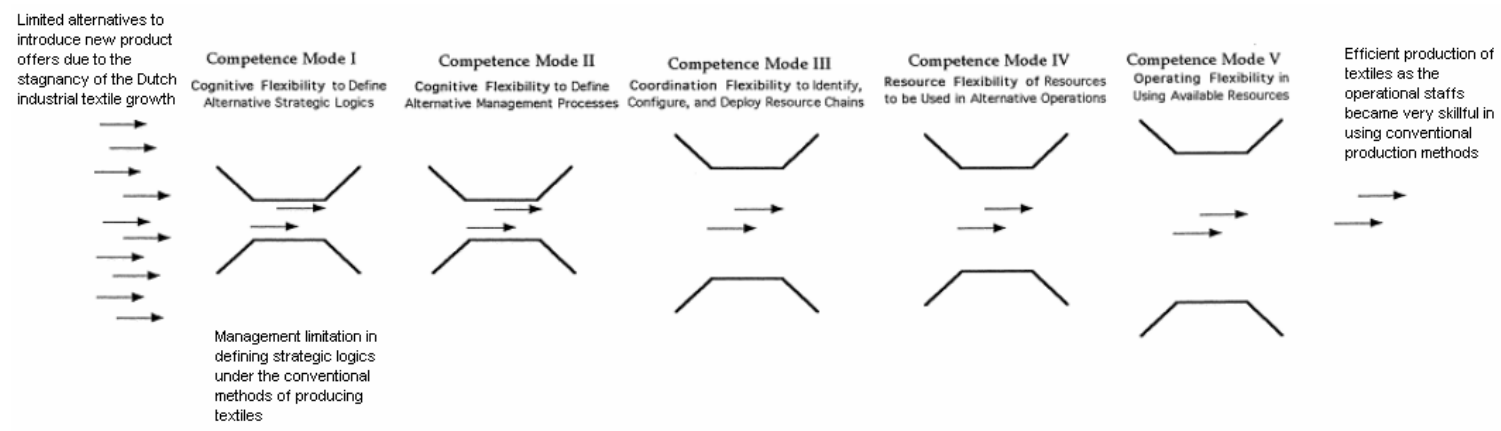

Figure 9. Bottleneck in the cognitive flexibility at the RTC's top management level due to the stagnancy of the Dutch industrial textile growth during 1800s to 1900s

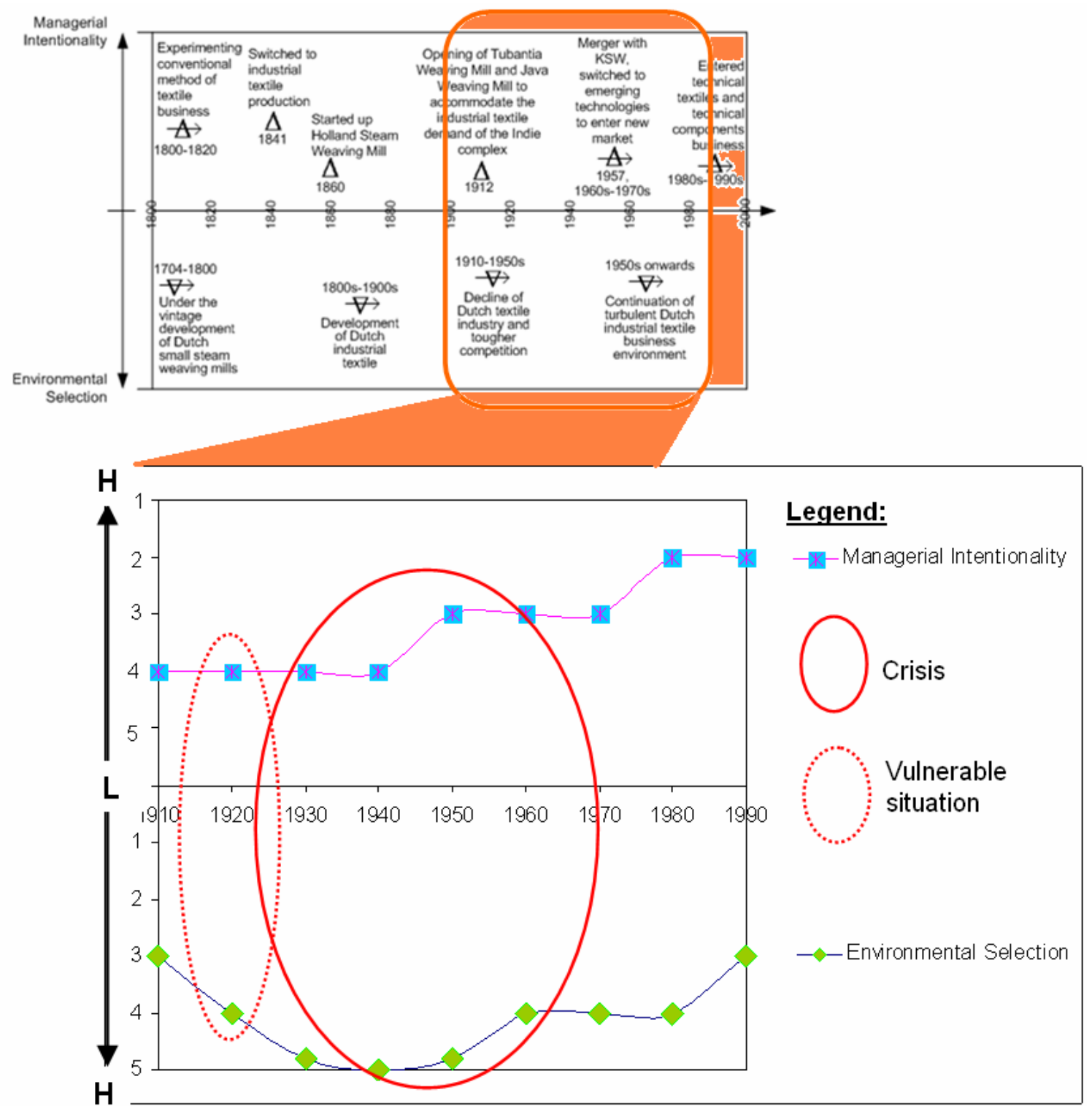

Figure 10. Zooming in on RTC’s Renewal Trajectory (1910-1990) 


\section{Publications in the Report Series Research ${ }^{*}$ in Management}

\section{ERIM Research Program: "Strategy and Entrepreneurship"}

2007

Longitudinal Study on the Performance of U.S. Pharmaceutical Firms: The Increasing Role of Marketing

L.H. Pattikawa

ERS-2007-020-STR

http://hdl.handle.net/1765/9400

The Impact of Corporate Venturing on a Firm's Competence Modes J. Henri Burgers, Frans A.J. Van Den Bosch and Henk W. Volberda ERS-2007-061-STR

http://hdl.handle.net/1765/10536

Why New Business Development Projects Fail: Coping with the Differences of Technological versus Market Knowledge J. Henri Burgers, Frans A.J. Van Den Bosch and Henk W. Volberda

ERS-2007-072-STR

http://hdl.handle.net/1765/10622

Investigating the Development of the Internal and External Service Tasks of Non-executive Directors: The Case of the Netherlands (1997-2005)

Pieter-Jan Bezemer, Gregory F. Maassen, Frans A.J. Van Den Bosch and Henk W. Volberda

ERS-2007-074-STR

Complex Incremental Product Innovation in Established Service Firms: A Micro Institutional Perspective Patrick A.M. Vermeulen, Frans A.J. Van Den Bosch and Henk W. Volberda

ERS-2007-075-STR

Coevolutionary Competence in the Realm of Corporate Longevity: How Long-lived Firms Strategically Renew Themselves Zenlin Kwee, Frans A.J. Van Den Bosch and Henk W. Volberda ERS-2007-076-STR

\footnotetext{
A complete overview of the ERIM Report Series Research in Management: https://ep.eur.nl/handle/1765/1

ERIM Research Programs:

LIS Business Processes, Logistics and Information Systems

ORG Organizing for Performance

MKT Marketing

F\&A Finance and Accounting

STR Strategy and Entrepreneurship
} 